\title{
Angus McEachen's house: the anatomy of an early 19th-century crofting settlement near Arisaig
}

Ross White*, Chris O'Connell* and Fay Oliver**

with a contribution by Sue Anderson*

* CFA Archaeology Ltd, Old Engine House, Eskmills Park, Station Road, Musselburgh EH21 7PQ

** Department of History, University of Stirling

Scottish Archaeological Internet Report 35, 2009 www.sair.org.uk 
Published by the Society of Antiquaries of Scotland, www.socantscot.org.uk with Historic Scotland, www.historic-scotland.gov.uk

and the Council for British Archaeology, www.britarch.ac.uk

Editor Helen Bleck

Produced by Archetype Information Technology Ltd, www.archetype-it.com

ISBN: 9780903903622

ISSN: $1773-3803$

Requests for permission to reproduce material from a $S A I R$ report should be sent to the Director of the Society of Antiquaries of Scotland, as well as to the author, illustrator, photographer or other copyright holder.

Copyright in any of the Scottish Archaeological Internet Reports series rests with the SAIR Consortium and the individual authors.

The maps are reproduced from Ordnance Survey material with the permission of Ordnance Survey on behalf of The Controller of Her Majesty's Stationery Office. (C) Crown copyright 2001. Any unauthorised reproduction infringes Crown copyright and may lead to prosecution or civil proceedings. Historic Scotland Licence No. GD 03032G, 2002.

The consent does not extend to copying for general distribution, advertising or promotional purposes, the creation of new collective works or resale. 


\section{CONTENTS}

List of Illustrations . . . . . . . . . . . . . . . . . . . . . . . . . . . iv

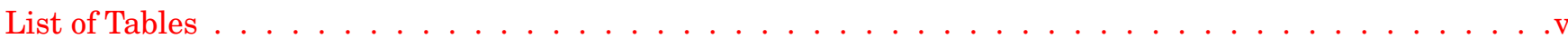

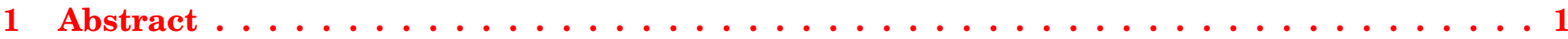

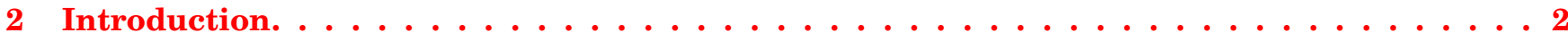

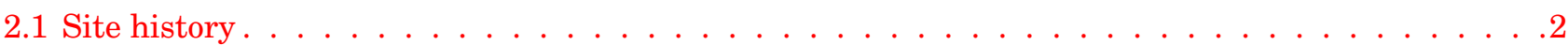

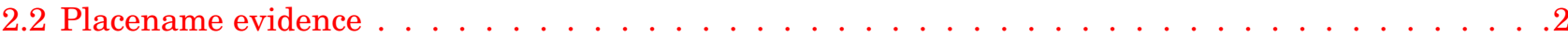

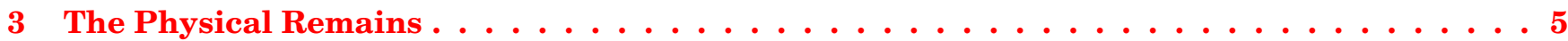

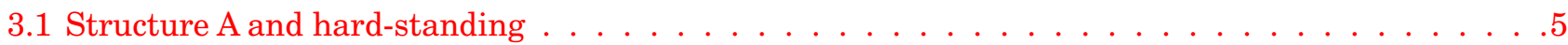

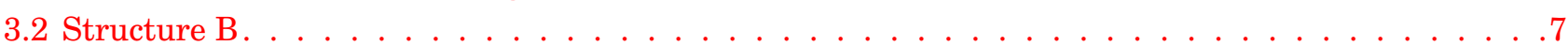

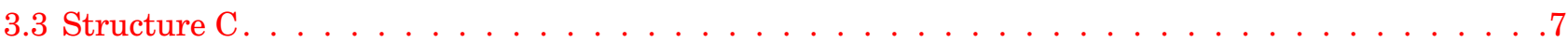

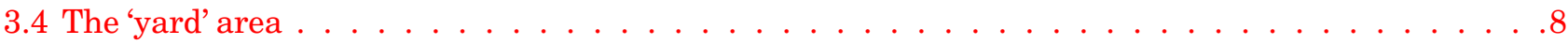

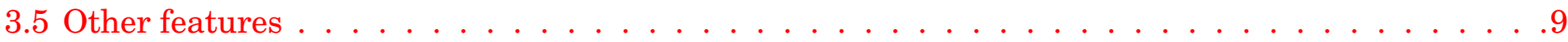

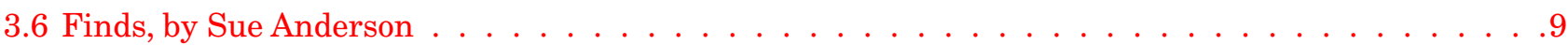

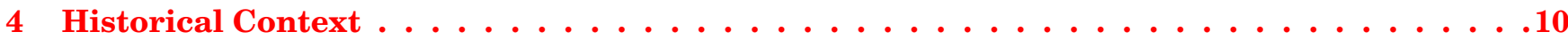

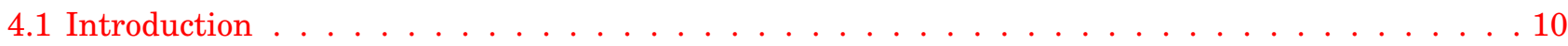

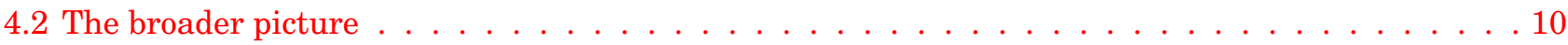

4.3 The inhabitants of the house at Brunary Burn. . . . . . . . . . . . . . . . 12

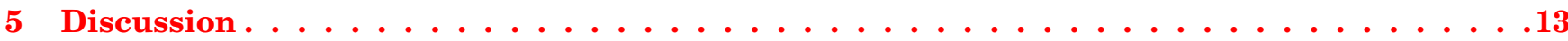

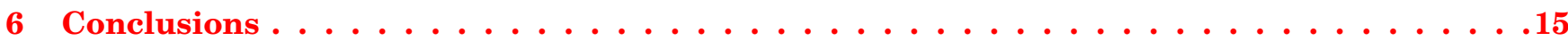

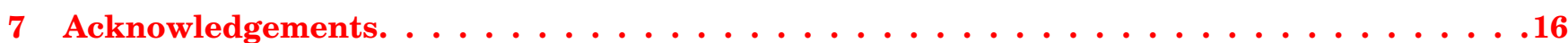

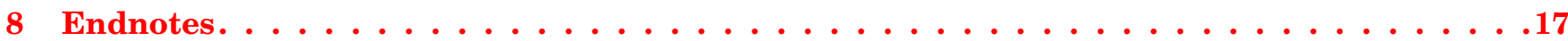

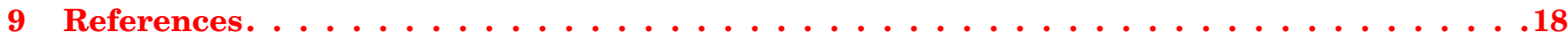

9.1 Cartographic references . . . . . . . . . . . . . . . . . . . . . . 18

9.2 Records held in the General Register Office, Scotland _ . . . . . . . . . . . . . . . 18

9.3 Papers and documents held in the National Archives of Scotland . . . . . . . . . . . . . . 18

9.4 Parliamentary Papers . . . . . . . . . . . . . . . . . . . . . 18

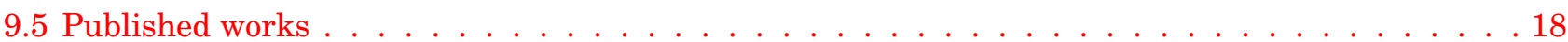




\section{LIST OF ILLUSTRATIONS}

Site location map. . . . . . . . . . . . . . . . . . . . . . . . . . 3

Brunary Burn site plan showing trenches, structures and other features . . . . . . . . . . .4

Plan of the Brunary Burn structures . . . . . . . . . . . . . . . . . . . . . . .6

Structure A from the north-east. . . . . . . . . . . . . . . . . . . . . . . . .7

Detail of wall composition in Structure A. . . . . . . . . . . . . . . . . . . . . . .

Detail of paving within Structure A. . . . . . . . . . . . . . . . . . . . . . 8 


\section{LIST OF TABLES}

$1 \quad$ Value of the Produce of Moidart, Arisaig and South Morar, $c$ 1807-33 . . . . . . . . . . . 10 



\section{ABSTRACT}

This report presents the results of an excavation and historical study of an early 19th-century settlement at Brunary Burn near Arisaig, Highlands (NGR: NM 6770 8578). CFA Archaeology Ltd carried out the excavation during October 2005 in advance of the realignment and upgrading works of the A830 between Fort William and Arisaig. Two rectangular drystone buildings were excavated, along with a yard area between them. Artefacts recovered included pottery, iron tools, cauldron fragments, slate roofing and clay pipe fragments. The project provided an opportunity to bring together social historical research with archaeological evidence for a somewhat archaeologically under-studied period, and also identified the former inhabitants of the settlement as Angus McEachen and his extended family. The buildings appear to have been occupied for perhaps a single generation before the family was evicted and moved to new accommodation within the area. 
This paper presents the combined results of an archaeological excavation and historical research undertaken into the social history of a 19th-century household at Brunary Burn. The ruinous house is the material embodiment of the life of the occupiers, the McEachens, who are in turn representative of a class of people who suffered greatly during a time of economic and social crisis in Scotland's history.

The advantages of a combined research strategy are manifold. Archaeological data can produce narratives without the support of written documentation or oral history. These narratives may span generations or millennia, or detail a single physical event such as making a clay pot. It is usually more difficult to reconstruct short-term events over a day or a generation, as they may leave no archaeological signature. Historical research on the other hand, with its myriad oral and documentary evidence, can elucidate past events, and the people involved, within many different timeframes. But, with its focus on written evidence, this form of research can also be prey to bias and mis-representation within the evidential documents, and can fail to supply detail relating to the physical aspects of life for the subjects. Archaeological research, however, is well placed, and has a long and practised methodology, for understanding material evidence. The combination of both these lines of research, archaeological and historical, can be a powerful analytical research tool.

\subsection{Site history}

Brunary Burn lies in the district of Arisaig in the Western Highlands. Together with neighbouring districts of Ardnamurchan, Moidart, Morar and Knoydart, this general area is often referred to as the 'Rough Bounds'. Bounded to the north by Loch Hourn and to the South by Loch Suinart, with mountains, innumerable sea- and freshwater lochs, and a dramatic coastline, the area is almost archetypically Highland in its natural beauty. The Rough Bounds, however, also refers historically to the difficulty of the terrain, the almost impenetrable nature of much of the landscape, and the isolation of the population. This remoteness only came to an end relatively recently; the West Highland rail line was opened at the end of the 19th century with the extension to Mallaig completed in March 1901 (Thomas 1979, 11), a regular steam ship service began earlier (Durie 2003, 47-55), and, prior to this, the road from Fort William was completed in 1812 (Rixson 2002; though, at the time of writing, there are still some single-track sections near Arisaig).
The site was located $120 \mathrm{~m}$ to the south of the present A830 (NGR: NM 6770 8578; illus 1). It lay at $c 50 \mathrm{~m}$ above $\mathrm{OD}$, in a clearing of trees on rough pasture and boggy ground on the west side of the Brunary Burn. The buildings were previously recorded as part of a survey carried out in 1994 (Alexander 1994). The excavation area was heavily overgrown with bracken and other vegetation. To the south of the main excavation area lay boggy ground and to the west lay a large glacial drumlin or knoll.

CFAArchaeology Ltd carried out an evaluation of the two partially upstanding buildings at Brunary Burn (NMRS No NM68NE 42) in June and July 2005 (Suddaby 2005). During this work, the building interiors were investigated by trial trenching and a series of test pits investigated the area between the houses. A programme of excavation subsequently took place focusing on the buildings and area between the houses, as well as the recording of ancillary features, in September and October 2005. The excavations were required as the site would be covered by the construction of an embankment on the approach to the new bridge over the Brunary Burn as part of the A830 upgrading. A watching brief was later conducted during topsoil stripping associated with the road construction in the summer of 2007, to monitor the removal of the buildings and the stripping to natural subsoil by mechanical excavator; no further archaeological remains were discovered. The archaeological work was commissioned by Historic Scotland on behalf of Transport Scotland, an agency of the Scottish Executive.

Several other archaeological sites, recorded in the National Monuments Register for Scotland (NMRS), in the vicinity of Brunary Burn, were of particular relevance to this study (illus 2). They were a drystone building with associated rig and furrow (NM68NE 41); field banks and quarries at Druim an Darich (NM68SE 19); field banks at Torr an t-Sagairt (NM68NE 40); a drystone rectangular building (NM68NE 35); a township comprising eight buildings (NM68NE 35); and a rectangular turf structure (NGR: NM 6583 8835)

\subsection{Placename evidence}

It has been suggested that some of the placenames in the immediate area of Brunary Burn contain evidence for a religious settlement of early date: Torr an t-Sagairt (mound of the priest), Lochan Torr na Nighinn (little loch of the mound of the sisters (or nuns)) and Lochan a Chléirich (little loch of the cleric) (R McCullagh, pers comm). Torr an t-Sagairt 


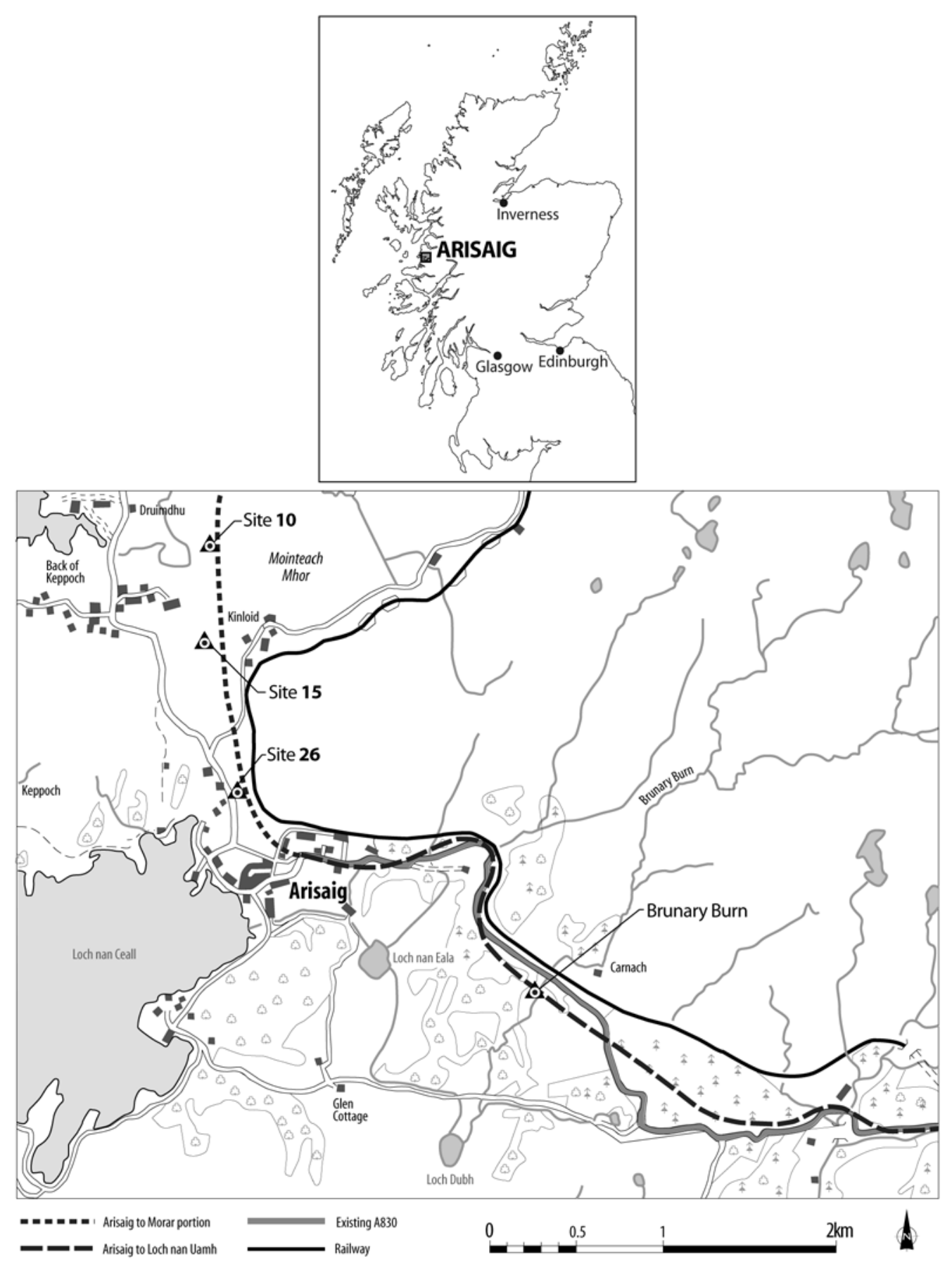

Illus 1 Site location map

could be explained by the fact that the Statistical Accountsmention preachers travelling to the Kinlochmoidart area to preach to their flocks; if this were to be done in the open air, then the preacher may have used the drumlin as a natural dais and vantage point. The excavations at Brunary Burn recovered no supporting evidence for an early religious site, however, it is doubtful that the activities of peripatetic preachers would leave much physical evidence of their presence. 


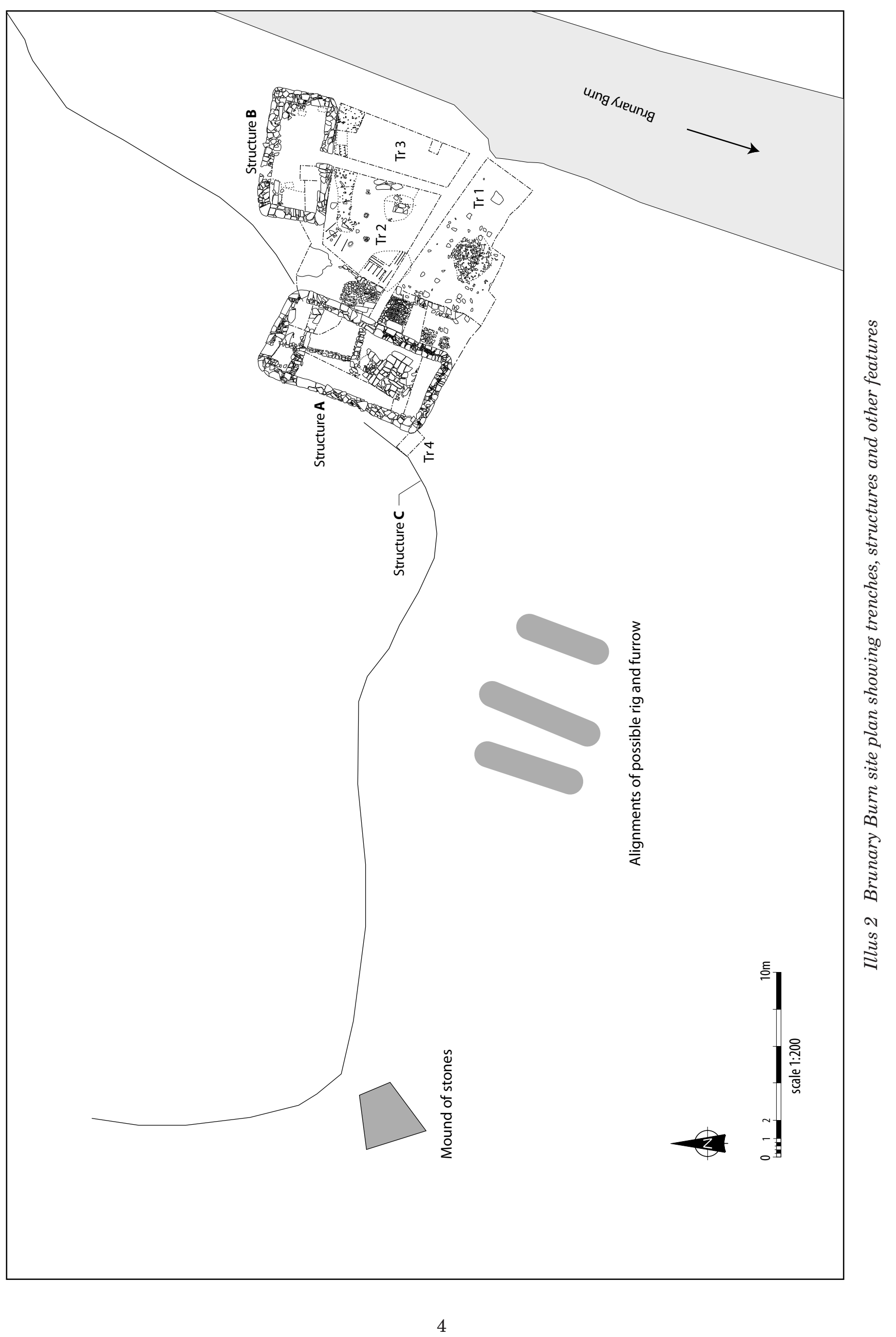




\section{THE PHYSICAL REMAINS}

A mitigation strategy was agreed with Historic Scotland prior to construction work commencing on site and following the evaluation work (Suddaby 2005). The internal areas of the structures $A$ and $B$ were to be fully investigated and their walls recorded $\left(c 45 \mathrm{~m}^{2}\right)$. A small trench $\left(c 4 \mathrm{~m}^{2}\right)$ was proposed at the junction of structures $\mathrm{A}$ and $\mathrm{C}$ to establish their stratigraphic relationships. The excavation of a trench $c 100 \mathrm{~m}^{2}$ in the area between the two buildings permitted investigation of the paved area and other features identified in the evaluation. Features were to be sampled for information gain rather than fully excavated.

Topsoil removal during both the evaluation and the excavation was conducted by hand, as machine access was restricted due to the terrain. The removal of the topsoil revealed a deposit of mottled orange and yellow sandy silt over most of the site.

The building remains were assigned the identifiers Structure A and Structure B. Structure C was a possible wall to the rear of Structure A, at the base of the knoll. The internal areas of the buildings were exposed and excavated, where possible, and sections excavated through walls to investigate construction techniques. Health and safety considerations meant that some areas were unsafe to excavate. An approximately $100 \mathrm{~m}^{2}$ 'yard' area between the houses was included within Trenches 1,2 and 3 (illus 2), leaving an unexcavated strip $c 3 \mathrm{~m}$ wide along the bank of the burn to facilitate turf storage, reduce the risk of flooding and allow access to the site. These three trenches were eventually combined to give a full view of the excavated area between the houses (illus 3). A fourth trench, measuring $3 \mathrm{~m} \times 1.5 \mathrm{~m}$, was excavated at the south-west corner of Structure A to expose part of Structure $\mathrm{C}$ and to investigate the relationship between the two structures (Trench 4, illus 2).

In addition, an area of rig-and-furrow and a mound of stones were recorded by Total Station survey, to the west of the main excavation area (illus 2).

The following text describes the findings of the excavation. Full context descriptions are held in the site archive, which will be deposited with Royal Commission on Ancient and Historic Monuments in Scotland (RCAHMS).

\subsection{Structure A and hard-standing}

This structure (illus 3) had an internal floor space $8 \mathrm{~m}$ by $3.5 \mathrm{~m}$ and was orientated NE to SW. It was rectangular in plan, with squared internal corners and rounded external corners (illus 4). The walls were approximately $0.65 \mathrm{~m}$ wide and survived to a maximum height of $1.5 \mathrm{~m}$. They were of drystone construction and consisted of three elements: an outer face of roughly dressed, very large bouldersized stones (1013); an angular cobble-sized stone core (1015); and an inner face of roughly-dressed, flattened large cobble-sized stones (1014; illus 5), their flat sides facing into the interior of the structure to present a relatively smooth surface. A central entrance and two possible window frames were identified in the eastern wall of the structure. Judging by the size and insubstantial nature of the building remains it is probable that the building was of single-storey construction.

An internal wall (1017) was identified and appeared to represent a partition separating a small compartment, possibly a storeroom, from the rest of the building. A threshold stone showed where the doorway between the main chamber and the compartment had been situated. With the exception of this small chamber, there was no surviving structural evidence to indicate that the main room had been subdivided.

Part of the southern half of the floor area was paved with large, flat flagstones (1016; illus 6 ). These flagstones did not form a perfectly flat surface but were nevertheless carefully placed to form a neat hard-standing within the building. A small possible hearth was identified just off-centre in the house, within the northern part of the surviving paving. It consisted of a shallow $(0.04 \mathrm{~m}$ deep) patch of burnt soil (1038) which abutted a small sub-circular setting of cobbles (1045), some displaying signs of fire damage.

The surface in the northern half of the interior comprised an earth floor, or represented the level upon which paving had formerly been present. It is possible that the whole of the interior of Structure A was paved, and that post-abandonment robbing is responsible for the small area of paving remaining.

A network of interconnecting under-floor drains (1023, 1030 and 1032) was identified within the interior of the building. The drains were flat-based, vertical-sided and lined with sub-angular and flat cobbles and connected together to run west to east below the entrance flagstones.

Externally, an area of hard-standing was identified on the east side of the building (1039), which ran for approximately $1.5 \mathrm{~m}$ to the north of the entranceway and $4 \mathrm{~m}$ to the south of the entranceway. It extended $2.5 \mathrm{~m}$ out from the east wall into the yard area and was raised above the rest of the yard by approximately $0.2 \mathrm{~m}$. A sondage through this feature revealed that it consisted of several layers of imported material to raise up and level the ground outside the main house. It probably formed a con- 


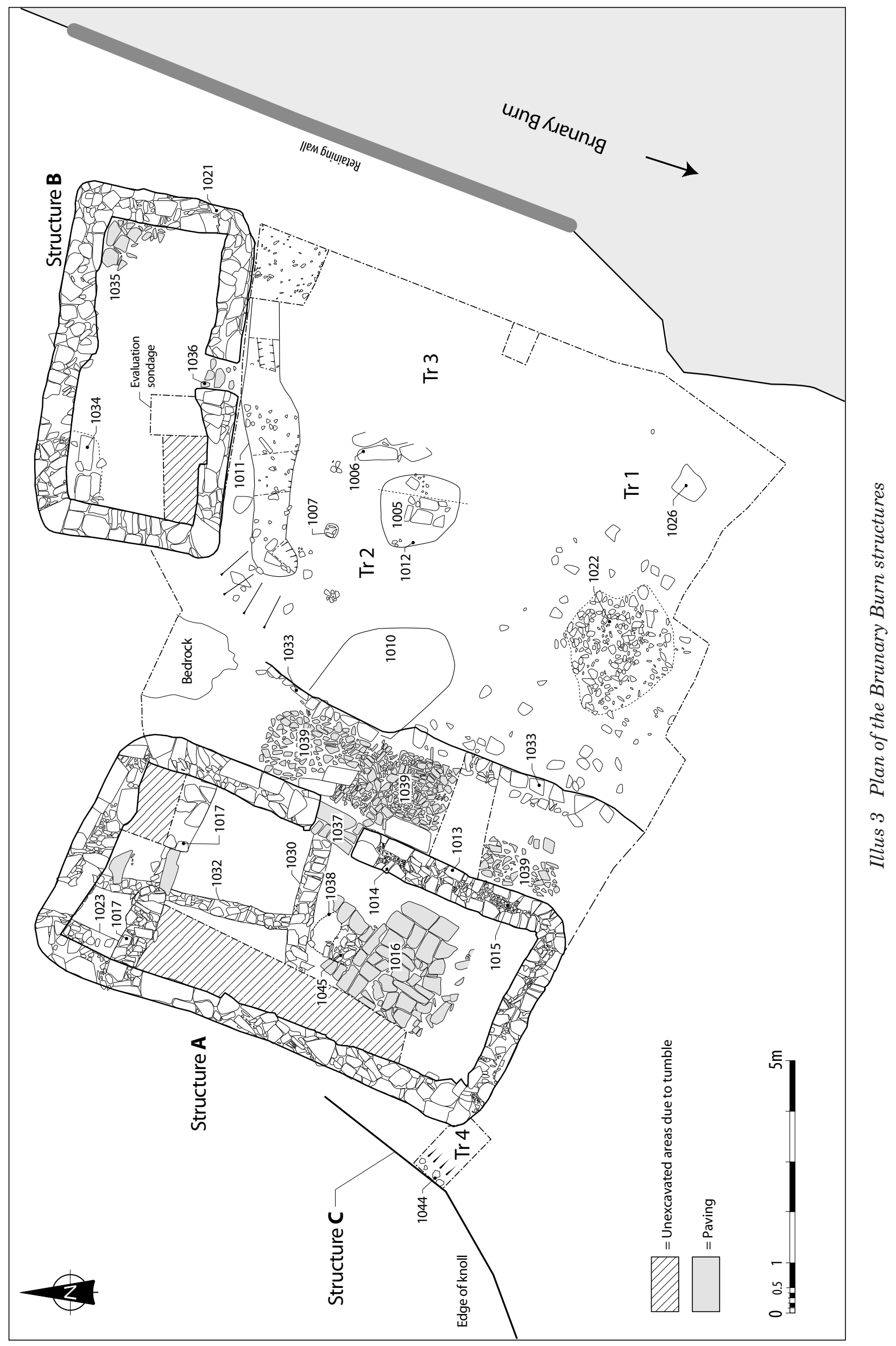




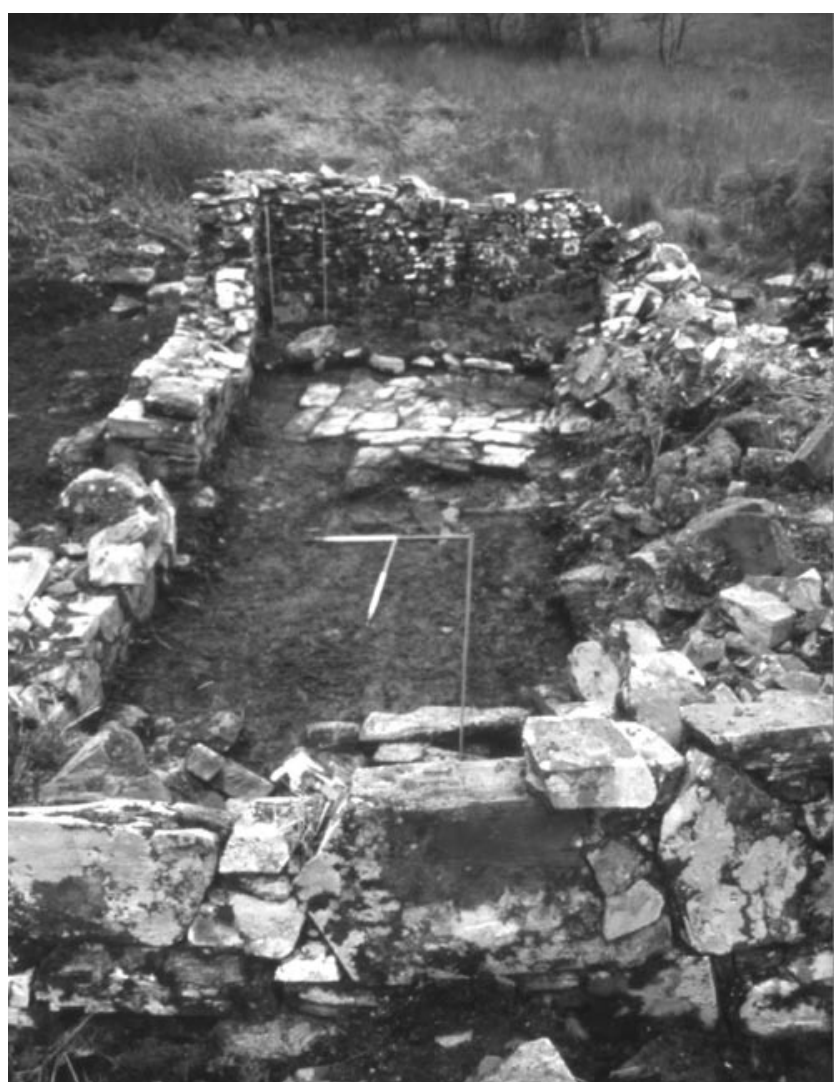

Illus 4 Structure A from the north-east

tinuation of the house platform itself. A kerb made of small sub-angular boulders (1033) separated and retained the hard-standing platform from the yard area in front of the house. The main drain (1030) terminated at the edge of the hard-standing. At the mouth of the drain a deposit of dark brown to black, organically rich, friable sandy silt (1010) was identified and contained a relatively dense concentration of pottery fragments, suggesting that it served as a waste collection area lying downslope and away from the house.

Removal of the structures and deposits within Structure A revealed that they were all set upon or cut into the natural mottled orange fine sandy silt subsoil (1003).

\section{$3.2 \quad$ Structure $B$}

This probable single-storey structure (illus 3 ) had an internal floor space of $5.5 \mathrm{~m} \times 2.5 \mathrm{~m}$ and was orientated approximately east to west. It was rectangular in plan, with rounded exterior corners and square internal corners. The walls (1021) were of very roughly dressed drystone construction one or two courses thick. They were approximately $0.6 \mathrm{~m}$ wide and the only gap noted was at the entranceway on the south side of the building. The walls survived to a maximum height of $1.3 \mathrm{~m}$. The building was situated on flat ground, abutting, or possibly slightly cut into, a knoll of bedrock on the western side. A mound of

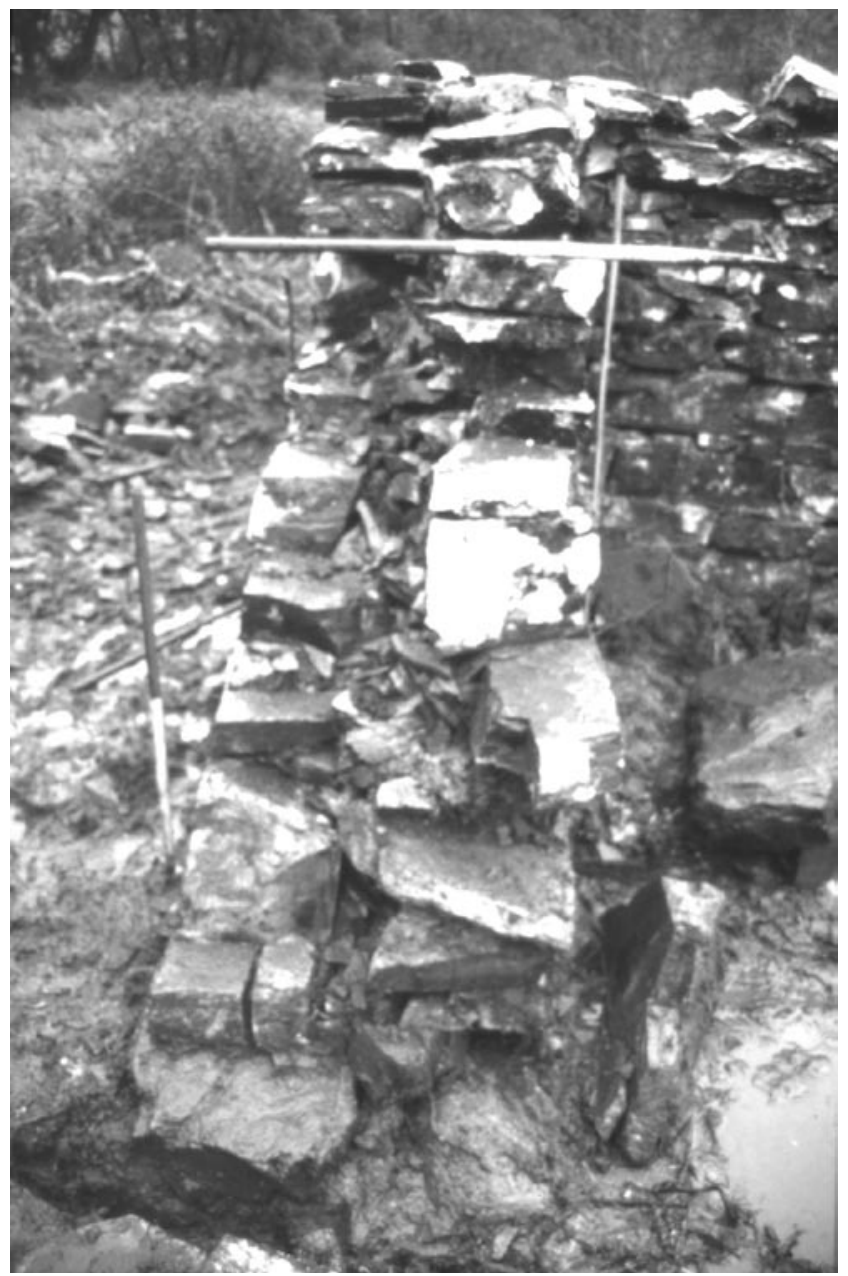

Illus 5 Detail of wall composition in Structure A

rubble was evident immediately to the north of the building, possibly the tumbled remains of walling, or debris from quarrying and stone trimming.

The interior of the structure was relatively devoid of features in comparison with Structure A. An area of possible rudimentary paving slabs (1035) was identified in the north-east corner, and a small setting of stones (1034) two to three courses high was identified in the north-west corner of the house.

Removal of Structure B confirmed that the building and floor deposits were laid on the natural subsoil (1003).

\subsection{Structure $C$}

One trench (Trench 4) was excavated to investigate Structure C; the structure thus revealed comprised the remains of a drystone field bank running along the base of the knoll to the west of the settlement. This field bank is shown on the First Edition Ordnance Survey map (1876), and appears to have been used to delineate the forested area from the boggy ground around Lochan Torr na Nighinn. The field bank lay $1 \mathrm{~m}$ to the west of Structure A and consisted of undressed cobbles (1044) laid against the slope of 


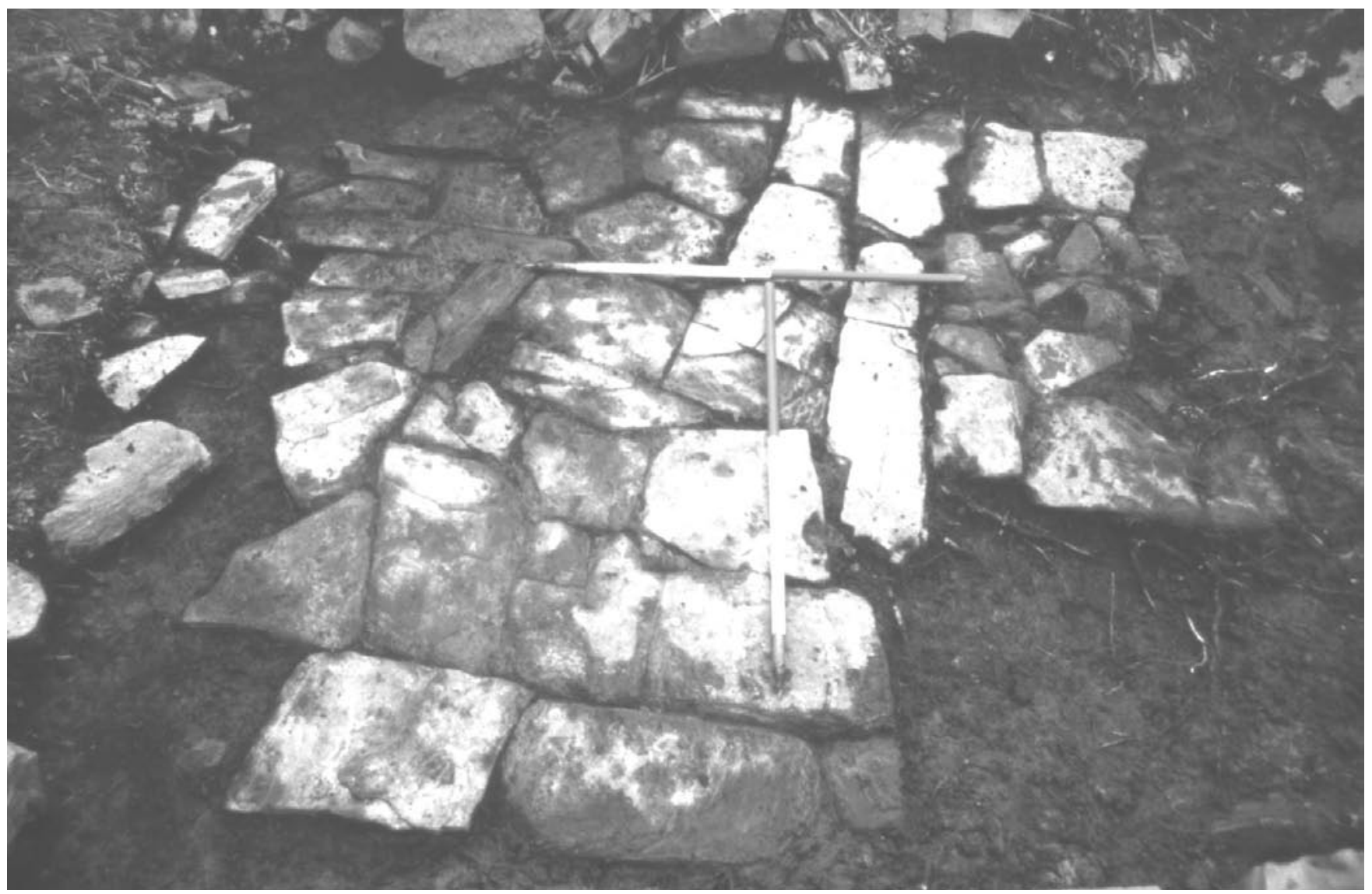

Illus 6 Detail of paving within Structure A

the knoll. Only $7 \mathrm{~m}$ of the bank was visible (illus 2). No stratigraphic relationship could be ascertained between the field bank and Structure A, but the nature of the construction and the proximity of the two structures suggests that they are probably contemporary. During the watching brief no continuation of the field bank was identified, presumably having been robbed out.

\subsection{The 'yard' area}

The southern half of the yard area, or area between the houses (illus 3) was littered with tumble from the buildings. The topsoil contained dense bracken and tree roots, rough grass and moss. Topsoil removal revealed spreads of greyish brown sandy silt with occasional charcoal flecks (1001), these spreads being more prevalent in the north of the trench and attributed to silting episodes from flooding. The natural subsoil (1003) was exposed throughout this area, and several features were cut into or laid straight onto this natural subsoil.

An approximately oval spread of stones (1022), or possible platform, measured $2.5 \mathrm{~m}$ by $2.1 \mathrm{~m}$ lay on the natural subsoil. The spread appeared to form a rough hard-standing area, perhaps for use as a working area in front of the houses. Alternatively, as it contained the largest group of pottery from the site, it may have been an area in which refuse was concentrated, perhaps for manuring purposes.

A hearth was identified in the centre of the yard. It was sub-square in plan and consisted of large cobbleand small boulder-sized flagstones (1005). These stones were surrounded by a spread of dark greyblack silt with ashy inclusions (1012). A platform of large boulder-sized flagstones (1006) was identified to the north-east of 1005 . The platform was rectangular in shape, $1.1 \mathrm{~m} \times 1.5 \mathrm{~m}$, and consisted of approximately 12 stones laid directly on layer 1001.

A post-hole (1007; illus 3 ) was identified just to the north-west of the hearth. It was sub-square in plan and measured $0.24 \mathrm{~m}$ in diameter and $0.2 \mathrm{~m}$ deep. It was filled with dark grey, loosely compacted sandy silt, with four packing stones. Two small concentrations of cobbles lay equidistantly $1.2 \mathrm{~m}$ to the east and west of 1007. These may have been the remains of post-holes that had silted up, thus masking any cut feature. If these were indeed post-holes then the three features would have formed a straight line, possibly the remains of fencing or a windbreak or other temporary structure associated with the hearth 1005 and possible working area 1006.

A small sub-square spread of black sandy silt (1026) of indeterminate function lay in the far southeast of the site.

A linear, shallow cut feature (1011; illus 3), 3.3m 
long $\times 0.75 \mathrm{~m}$ wide, ran parallel with Structure B's southern wall; its western extremity curved round slightly to the south. It had shallow sloping sides and a curved base, on average $0.18 \mathrm{~m}$ deep. It cut through layer 1001, and contained sandy silt fills. This feature probably served as a soakaway or drip channel for rainwater running off the roof of Structure B. Stones present within the uppermost fill were possibly added later to act as a hardstanding area, similar to, but more insubstantial than, that seen to the east of Structure A, as water running from the roof would have made the ground particularly boggy.

A drystone revetting wall (illus 3) ran along the western bank of the burn, which survived in places to a height of $0.8 \mathrm{~m}$, a maximum of ten courses high. This wall had presumably been built to slow the erosion of the bank of the burn, thus helping prevent flooding of the settlement.

\subsection{Other features}

An alignment of three rig-and-furrow features was identified to the west of the settlement (illus 2 ). The crests of the rigs were spaced on average $2.75 \mathrm{~m}$ apart, and aligned approximately north-east to south-west. The maximum length of the rigs was $5.5 \mathrm{~m}$ before they disappeared into the bog to the south of the settlement. The watching brief failed to find any sub-surface traces of the three features, but the topsoil was deeper, up to $0.6 \mathrm{~m}$, at the crest of the rigs, and $0.45 \mathrm{~m}$ deep at the trough of the furrows. The topsoil was very wet, peaty and boggy and overlay bedrock.

A mound of large cobbles and small boulders lay at the base of the west side of the knoll (illus 2). It measured approximately $2.8 \mathrm{~m} \times 3 \mathrm{~m}$. The watching brief confirmed that this feature was an ephemeral and insubstantial mound of loose stones, not forming any structure and laid on and within the topsoil and bedrock outcrop. It is not possible to associate this mound of stones with the settlement, but the stones were of a similar size to those used in Structure C.

\subsection{Finds, by Sue Anderson}

\subsubsection{Pottery}

The site produced 139 sherds (668g) of pottery. With the exception of one small sherd of glazed red earthenware, the assemblage was dominated by refined whitewares of 19th-century date, including industrial slipwares, mocha ware, spongewares, hand-painted and transfer-printed wares. The wide variety of decorative techniques and forms present meant that it was possible to identify a maximum of 26 vessels in this small assemblage. A full list is included in the archive.

The majority of these decorative techniques were employed by many potteries in Scotland and further afield. It is not possible to attribute any of the sherds from this site to a specific factory, but the most likely sources would be the Glasgow potteries or those close to the west coast ports of England (Cruickshank 1987).

Most of the vessels were associated with Structure A, although some were widely dispersed. For example, sherds of a spatterware bowl were found in the general topsoil layer over Structure A, the possible sump 1010, and two evaluation contexts within the structure. Sherds of a spongeware bowl were similarly scattered, in the topsoil, buried garden soil 1001, sump 1010 and stone spread 1022. With the exception of finds from topsoil, the context producing the largest number of sherds was stone spread 1022, possibly indicating that there was some intentional concentration of rubbish in this area. However, the general scatter of vessels tends to suggest that not all broken pottery made it to a midden or rubbish dump and that the occupants may have been relatively careless with the disposal of their refuse. The presence of sherds of individual vessels within both buried features and the topsoil indicate that much of the pottery scattered in the overlying layers was contemporary with the life of the structures and that some was redeposited post-abandonment, perhaps through root or animal action.

The wide variety of broadly contemporary 19thcentury vessels in this group may be a result of the pieces' being 'handed down' to their final owners. They may well have been second- or third-hand by the time they reached the site, thus explaining the lack of 'sets'. Some of the vessels may have been treasured possessions, as attempts had been made to mend them. Several sherds from five vessels (a spatterware bowl, a mocha ware teapot, a pearlware plate, a hand-painted bowl and a small rim fragment) had small drilled holes close to the edges, one with iron staining suggesting the use of iron wire staples to hold them together. As one was a teapot, clearly this was not for continued use as wiring would not have made the vessel watertight, so the item must have been intended for display.

\subsubsection{Other finds}

Other 19th-century finds included a fragment of a glass bottle rim, two clay pipe bowls, iron tools (pick axe and hammer), cast iron cauldron fragments, pieces of slate roofing and a small quantity of heavily calcined animal bone. One of the clay pipes had a short spur and was probably of early to mid 19th-century date; it came from hard-standing cut 1011. Most of the other finds were recovered from topsoil and test pits. The assemblage probably represents domestic debris from the household occupying the structures, which was scattered post-abandonment. 


\section{HISTORICAL CONTEXT}

\subsection{Introduction}

Brunary Burn was likely to have been constructed in the early 19th century, as part of the attempted development of the Highlands by landlords keen to maintain population and bring marginal land into cultivation. The poor nature of the land on which the houses are located would suggest it was not possible to make more than a partial living from it. This in turn suggests that the excess labour was being used in collecting kelp, a valuable (for a time) cash crop for Highland landlords.

The property does not appear on any maps or plans of the area before it was abandoned, indicating that it was not regarded as being of much significance or financial worth. The buildings first appear on the First Edition Ordnance Survey map (1876), and are shown as two unroofed buildings, indicating that the buildings had been abandoned by this point. No buildings are shown here on Roy's 1747 map of the area. Census records reveal that part of the property (Structure A) was inhabited by a crofting family, the McEachans, in 1841 but, thereafter, there is no mention of it in subsequent censuses. In turn this suggests that the property was abandoned in the 1840s during the years of the great Highland famine, possibly through forced eviction. Research suggests that the family moved to another croft nearer the village of Arisaig, though it is likely that some of the inhabitants emigrated, with Canada as their most likely destination (Dobson 1984, 108-10).

\subsection{The broader picture}

Beginning in the 1760s the intrusion of sheep farms began quietly but inexorably, and took over the Highlands and Islands in a series of waves over the following decades. It is important, however, to recognise the other forces at work. Eviction and clearance were not necessarily linked to sheep; basic enclosures on the pattern of southern improvement were common, creating larger farms for cattle and arable production. Within the broad sweep of clearance each locality had distinctive experiences. The New Statistical Account (NSA 1845) provided a basic valuation of the produce of Moidart, Arisaig and South Morar according to the average prices for the 25 years preceding 1833 . This reveals the significance of sheep, cattle, kelp and potatoes (Table 1). Kelp was collected on the shore at Arisaig and Rhu, only a short distance from the house at Brunary, and played a particular role in the history of the area. During the time of the kelp boom (1790s to 1815) the principal landowner of the area, Clanranald, depended far more on this industry for his wealth than land rentals.

Table 1 Value of the produce of Moidart, Arisaig and South Morar, c 1807-33

\begin{tabular}{lr}
\hline Produce & Value \\
\hline Wool & $£ 2800$ \\
Oats & $£ 700$ \\
Bear [barley] & $£ 300$ \\
Potatoes & $£ 2250$ \\
Hay & $£ 833$ \\
Pasture, sheep & $£ 4375$ \\
Pasture, cattle & $£ 3000$ \\
Gardens \& orchards & $£ 150$ \\
Woods \& plantations & $£ 500$ \\
Fish & $£ 150$ \\
Kelp & $£ 2600$ \\
\hline
\end{tabular}

Clanranald's affairs became 'embarrassed' in 1811, and he 'conveyed all his estates to trustees'. The collapse in the price of kelp after the defeat of Napoleon saw Clanranald's embarrassment only deepen, and in 1824 his estates were being advertised for sale. Selling had become a necessity because the depreciation of the value of Highland property after 1815 meant that the estate could not meet its outstanding debts, and selling part of the estate was a strategy to try and protect the inheritance of the younger children. The price agreed was $£ 49,300$, and the bulk of this, $£ 44,500$, was paid in November 1827. Thereafter a lengthy dispute occurred between the two sets of trustees, with the issue going to arbitration before the final settlement in Clanranald's favour in $1833 .{ }^{1}$

Even this injection of new capital proved unable to save the estate, which was back on the market soon after. With this the role and very presence of the Clanranalds came to an end, and Arisaig and the other parts of the estate experienced a new wave of outside proprietors. The local minister of the Church of Scotland spoke at the Napier (or Crofter's) Commission in $1884:^{2}$

The estate of Arisaig and South Morar has the misfortune to have passed more than the ordinary changes of proprietors and factors within a couple of generations ... It is not so very long ago since Clanranald reigned here, followed by Lady Ashburton, Lord Cranstoun, Mr MacKay, and FDP Astley. Then came a trusteeship during the 
minority of Mr Frank Astley, who succeeded. He was not long in possession when he was succeeded by his sister; and now the estate has the further change incident of that lady's becoming Mrs Nicolson.

While there seems to have been some affection held by the tenants for FDP Astley, there was little for Lord Cranstoun, who was the proprietor during the famine years. In the evidence to the Napier Commission, clearance tended to be associated with Cranstoun's time. Denis Rixson, however, using the evidence collected by the Deer Forest Commission in 1894, identifies clearances in Arisaig as early as the $1820 \mathrm{~s}$, that is, during the Clanranald/Ashburton proprietorship (Rixson 2002, 126, fig 12). Nonetheless, most of the various clearances during the later 1830 s, 1840 s and 1850 s did occur under Lord Cranstoun. Cranstoun was certainly not a popular proprietor, and a negative view of his stewardship was not the preserve of displaced tenants. During the famine Cranstoun was seen as one of those landlords who failed to make an effort to bring relief to his tenants. It was recognised as early as the autumn of 1846 that there was 'a great deal of destitution' in Arisaig and that there was a total lack of work on Cranstoun's estate. ${ }^{3}$

The potato blight reduced the population to neardestitution, trying to survive on birds, fish and even edible seaweed. The recently created Free Church of Scotland was the first body to get relief into the Highlands and Islands. Its Destitution Committee raised $£ 15,000$ and sent provisions into the affected areas aboard the schooner Breadalbane. The Church concentrated its efforts on the cottars, the poorest class and most vulnerable, and, to its great credit, brought relief to the worst affected localities regardless of denomination; Catholic Arisaig was helped when the Breadalbane docked at Rhu. The government officials in charge of the national relief effort were determined not to provide 'gratuitous' relief. Their view was that the 'natives' had brought much of the misfortune on themselves, and any 'charity' had to come with conditions attached, in particular a demand that work be done for aid given. They were equally determined that the proprietors should not be given a blank cheque; they should be encouraged to improve their estates through drainage and road works via loans rather than grants. The success of such a strategy relied on the willing cooperation of the landlords, which put Arisaig in an unfortunate position. Cranstoun did grudgingly offer some road work on the estate but refused to supply the tools for the job (Devine 1988, 126).

Cranstoun was alive to the predicament he faced as a landlord, and there was a flurry of evictions and clearances in 1843 (Rixson 2002, 126). Unfortunately for our immediate purposes, there is no mention of Brunary Burn in the sources on Arisaig's clearances, but given that we know it was definitely inhabited in 1841, and disappears from the census thereafter, it is likely that the McEachan family was one of the many cleared in 1843.

At the Napier or Crofters' Commission in 1884 one of the witnesses was an Alexander McEachran, then 51 and a cottar. Alexander recalled being evicted from his family's croft at Kinloid about 30 years previously when he was nearly $20 .{ }^{4}$ The census of 1851 reveals that an Alexander MacEachan, 19, was resident at 'Farm of Kinloid' with his father, mother and three siblings. Their near neighbour, also at 'Farm of Kinloid' was the MacEachan family ex of Brunary Burn (as revealed by the information contained in the enumerator's schedules for both census years); the two families, who were likely related, had shared the same experience of clearance, not once but twice. After being put out of Brunary Burn, the MacEachans were then cleared from Kinloid and in 1861 were still in Arisaig, but at Back of Keppoch.

Arisaig, as with the rest of the Western Highlands and Islands, experienced continuous population growth for the best part of a century, from the mid 18th century till the 1840s. The rate of growth, however, was not as dramatic as that for the Lowlands and the central belt of Scotland. The census figures from the early part of the 19th century for the Inverness part of Ardnamurchan Parish reveal a slight increase between 1801 and 1841 . The break came in the 1840s, with the population figure for 1851 being exactly the same as it had been 30 years previously $(2,333) .{ }^{5}$ The population continued to decline thereafter: in 1881 the census recorded the population of 'Arisaig' as 1,136, and in 1891 as 929. At the latter date this population comprised 207 families of 447 males and 482 females. There were 204 inhabited houses, with 19 uninhabited, and none in the process of being built. The sharp disparity in wealth and comfort was revealed in the figures for the size of houses: 26 families lived in oneroomed houses, while 63 lived in two-roomed houses (the largest single category). At the other end of the scale were the big houses: there were 13 families living in houses of more than ten rooms, including two houses with more than 30 rooms.

At the sitting of the Deer Forest Commission in Arisaig in 1894, the crofters and cottars were examined. Both cottars and crofters desired land. In the case of the former there were some who had no land whatever, and the rest had only small patches of land or gardens where they grew potatoes. Their desire was for smallholdings which could provide part of their needs, with the rest provided by work elsewhere. The wish of most of the crofters was to have a new croft, larger than the smallholdings they currently held. Another witness (another MacEachan), Allan MacEachan from South Morar, explained that his croft had one acre of land only, plus the right to graze one cow on a neighbouring farm. In general the crofters in the area had no sheep or grazing land, only arable. Allan was 64 and had five sons aged between 13 and 21, all but one of whom were still living at home. His croft was unable 
to support his family and he and his sons made their living by labouring. There was little if any work provided by the estate and they got only the odd day's work wherever they could, which meant travelling 'throughout the country'. Allan would have preferred a new croft nearer the sea, because he had worked at fishing previously, though his sons had no experience of it. ${ }^{6}$

Covering Arisaig and South Morar, the estate of the Nicholsons in 1901/02 was a mixture of sheep farms, deer forest and crofts. ${ }^{7}$ Contrary to the crofters' claims that new, enlarged crofts could pay an economic rent, the Nicholsons were adamant that crofting rents could never match the money got from the hill farms with their sheep, or the shooting rights for those willing to pay for the 'pleasure' of hunting the deer. The estate, therefore, was dependent for a large part of its income on catering to the sporting enthusiasm of the wealthy. Many of the evictions in the area were done in order to create space for the deer, and it is likely that Brunary Burn was one of these clearances.

\subsection{The inhabitants of the house at Brunary Burn}

It is in this state of flux that we find the McEachen family residing at Brunary Burn in 1841. In this census the only occupations recorded were those of the head of the household, in this case Angus McEachen, a crofter. As explained above, crofting was a term used to encompass a variety of occupations necessitated by the uneconomic size of land on which to subsist. We can only speculate regarding the composition of this mix of activities. The possibilities might have been any of the following: work in and around the Arisaig estate and nearby Arisaig House in the form of labouring (or more skilled work such as stone masonry), shepherding and domestic service; fishing; seasonal migration to the south of Scotland. Most of these occupations are recorded in the McEachen family groupings identified in later censuses.

By 1851 John McEachen had taken over as head of household and they occupied a farm at Kinloid.
Further details of the family after they left Brunary Burn are included in the archive report.

Despite all the limitations imposed by the lack of specified relationships in the census of 1841 , each individual was assigned a relationship in a way in which it is believed, on the balance of probability, reflects the most likely set-up:

\section{Angus McEachen, aged 60, Father \\ Sally McEachen, aged 50, Wife \\ John McEachen, aged 30, Son \\ Sally McEachen, aged 35, Daughter-in-law \\ Donald McEachen, aged 10, Grandson \\ John McEachen, aged 5, Grandson \\ Cirsty McEachen, aged 4, Granddaughter \\ Angus McEachen, aged 1, Grandson \\ Jannet McEachen, aged 10, Granddaughter \\ Kate McEachen, aged 20, Daughter}

Since the patch of land around the buildings at Brunary Burn is boggy in nature, it may be assumed that it was not suitable for keeping animals, rather for cultivation of potatoes in a ridge and furrow system commonly employed in the area known as 'lazy beds'. Lazy beds were a method of growing crops in poor soil and are normally found in the north-west. They were effectively raised seed beds of between two and five metres wide, with steep drainage channels running between and seaweed often used as the fertiliser to improve the ground. Made with the spade, lazy beds were 'more labourintensive than ploughing, though more productive, an important consideration if arable is at a premium' (Dixon 1994, 51). The actual human effort involved has been described as 'a backbreaking attempt to wring a living from a difficult environment' (Whyte \& Whyte 1987, 267). This method of cultivation was also suited to marginal land such as the kind at Brunary Burn. Also, if this area had been used for cultivation, as suggested by the finding of ridge and furrow remains, it would be incompatible with the keeping of large animals as they would trample the crop. Added to this, the presence of plentiful bracken on this plot is also an indication of former lazy-bed cultivation, as bracken is known to prefer such soil. 


\section{DISCUSSION}

This paper presents the results of archaeological and historical research that aids in elucidating the plight of a family during a period of social and economic depression in Scotland's history. It demonstrates how national economic strategies had a very real impact on the lives of families of a low socioeconomic status, with their fortunes being largely dictated by economic downturns, the decisions of a few wealthy landowners, potato blight leading to crop failure and forced evictions or 'clearances' all resulting in famine and the necessity to emigrate, leading to a decrease in the local population.

The McEachen family make a brief appearance in the historical record. They are first noted in the 1841 census, as a family of ten, living in a house of drystone construction on the west bank of Brunary Burn. The family are not recorded as residing at the house in the next census of 1851 , but some of the family members are recorded as living in a farm at Kinloid, with John McEachen listed as the head of the household, his occupation a stone mason and the tenant of a farm with three acres of land. Listed as living with him are his father Angus, now a widower, Christina his daughter and his two sons Angus and Ewen (a new addition to the family since the 1841 census). His daughter Janet is no longer listed, and his son Donald is recorded in the 1851 census as working as a farm servant on a 14-acre farm at Acharale. There is no mention of his sister Kate. The family appear once again to have been evicted from their home at Kinloid as they are recorded by the 1861 census as now living at Back of Keppoch.

Like other crofting families their life was one of subsistence. The discovery of rig-and-furrow or 'lazy beds' to the south-west of the house attests to the fact that they would have grown their own vegetables; probably potatoes, on a small agricultural scale. If they had grazing rights they may have kept a small number of sheep and maybe a cow for milk. To supplement what they could grow and rear, the crofters earned money through labouring. The kind of labour the crofters could be employed to do was varied, and largely dependent on the will of the landowner. For instance, when the estate was owned by Clanranald, the kelp industry was in boom times, and the crofters were employed on a seasonal basis in kelp production. When the kelp industry collapsed and the fortune of Clanranald declined, crofters found themselves without this income, with the subsequent landowners, particularly Lord Cranstoun, becoming less willing to provide necessary employment on the estate.

The house at Brunary Burn, like its residents, also has a short recorded history. There is no hint of a structure at this location on Roy's map of 1747 and, by the time of the first Ordnance Survey map of the area in 1876, the buildings are shown to be unroofed. This suggests that when the McEachens left their former home some time in the 1840s and moved to Kinloid Farm near Arisaig, as recorded in the 1851 census, the house was left abandoned and soon fell into ruin. There is no documentary evidence to show whether the McEachen family were the original occupants or whether other families had lived there previously, but there is circumstantial evidence. All datable artefacts recovered during the excavations were 19th-century or later, and it can be shown that much of the pottery at least was contemporary with the life of the buildings, even though some was redeposited following abandonment. No major structural repairs or realignments were evident in the houses, no earlier structures or features were identified below or around the houses, and no artefacts were recovered pre-dating the 19th century. This archaeological evidence, coupled with the historical and cartographic evidence, is suggestive of a single, short phase of occupation, possibly only within the two decades between the 1831 and 1851 censuses.

The houses as they stood at the time of excavation were in a ruinous state. The larger building, Structure A, was stone-built, with the possibility of a slate roof. The smaller adjacent building, the function of which could not be determined through excavation, was more lightly built. A cobbled yard was built in front of the house and would have been subject to repeated flooding from the adjacent burn, so much so that a revetting wall was built on its western bank.

The internal floor space of Structure A was small at $28 \mathrm{~m}^{2}$, or $2.8 \mathrm{~m}^{2}$ per family member. There was only one internal division in the house, creating a small room $1 \mathrm{~m}^{2}$, the function of which was probably a storeroom, as it was too small for a habitable room, and toilet facilities were probably outwith the house. This stone partition may have been added later as the walls were not keyed in to the main outer walls. One end, probably the south, would have formed the living and sleeping area (the 'ben-end' or best end) and the other the working area and kitchen (the 'but-end'), with a central hearth heating both. Box beds and/or wooden benches were probably arranged against the walls around the surviving paving. It is uncertain whether the northern end was also paved, but a compacted earth floor would not be out of place in the working end of a farm worker's cottage. A rammed earth floor was present in the longhouse at Balquhidder, for example, with stone flags only being present around the hearth area and entrance (Stewart \& Stewart 1988, 309). 
Effectively this meant that family life within the house was without privacy. The finds assemblage attests to their necessary thriftiness, with pieces of crockery being repaired with wire, but also demonstrates a little household pride in that some of the pieces, like the teapot, could not have been used and were probably for display only.

The other, smaller, building, Structure B, was of inferior construction, with thinner walls, and no evidence of windows as with the house, Structure A. The function of Structure B could not be determined through excavation. It may have been a byre for overwintering animals, if the McEachens had grazing rights, but probably not cattle as the doorway was too narrow. Allan MacEachan from South Morar, a witness at the sitting of the Deer Forest Commission in Arisaig in 1894 (see above), explained that his croft had one acre of land only, plus the right to graze one cow on a neighbouring farm. In general the crofters had no rights to grazing land, and few were able to keep sheep. It is more probable that Structure B was a storeroom for the few agricultural implements the family would have possessed, but it cannot entirely be ruled out that the structure was used as living quarters, perhaps on an ad hoc basis when conditions became too cramped in the main house.

Although the house was built on marginal land with a wet and boggy nature, and may have been prone to flooding, in other respects some care was taken when choosing the position of the house. The house was roughly aligned north to south, with the entrance and possible windows facing the rising sun in the east. The house was also nestled on the leeward side of a knoll which offered some protection against prevailing westerly and south-westerly winds, and sat in a hollow, which was interpreted as the result of quarrying stone for the construction of the house and the other associated buildings and walls.

The presence of roofing slates would suggest that at least one structure had a slate roof. Only a few slates were recovered from the topsoil, but it is possible that the others were collected when the house went out of use and taken elsewhere for reuse. Although no evidence of a chimney was found during excavation, the smoke from the house would have had to be vented if the roof was tiled. Alternatively, both buildings could have been thatched and no provision made for the venting of smoke. No timber framing or evidence of any other structures for supporting the roofs of the buildings was identified. It is likely that, if thatched, the roof would have been hipped, with the rafters sitting directly on wall plates.

There are other examples of what appear to be 19th-century houses with a short occupation span in the vicinity of Brunary Burn. A drystone structure (Arisaig An Sidean, Site 26, illus 1), aligned north-east to south-west was recorded on the south-west side of a knoll. It had an internal measurement of $3 \mathrm{~m} \times 7.7 \mathrm{~m}$, with a smaller lean-to building built up against the east gable. Although the building was unroofed at the time of recording, fragments of roof slate were recovered (Carter et al 2005, 18). This structure's position, orientation, size and construction material are very similar to those aspects of the house at Brunary Burn. The house does not appear on any maps, and must have been demolished by the time of the First Edition OS map of 1876, and has been interpreted as an isolated and early 19th-century house (ibid). An evaluation was carried out on a nearby small township of eight buildings with associated banks and cultivation remains, named Achraig on the First Edition OS map (Site 15, illus 1; ibid, 18). Only three of the structures were depicted as being roofed on the First Edition OS map; the other five were not mapped. Of the five structures that did not appear on the First edition OS map, four were evaluated. Two of these were found to be turf and stone built and two were entirely of drystone construction. The finds assemblage was early to mid 19th-century, and there was no evidence of an earlier phase of occupation. A third site north of Achraig (Site 10, illus 1) was interpreted as a late 19th-century turf building (ibid, 17-18). What these sites have in common with Brunary Burn, as well as some similarities in aspect and construction, is the fact that all the houses appear to have had a relatively short lifespan. They appear on no maps prior to the First Edition OS map, six of the structures do not appear on it at all, and Brunary Burn is depicted as ruinous. They all have a probable 19th-century origin and there was no evidence of earlier occupation on the sites.

A building which exemplifies the suggested appearance of the Brunary Burn structures drystone walling with a hipped thatched roof - is preserved as the 'Cottar's House' at Auchindrain Museum near Inverary (Brunskill 1987, fig 132).

One possible interpretation of these sites is that they were a response to the growing kelp industry in the area and the increasing population, mirroring the rise of the industry in the early 19th century, with eventual economic slowdown and population decrease witnessed in the $1840 \mathrm{~s}$. As a direct result of the clearances, famine and emigrations, these houses were abandoned and left to fall to ruin.

Like many other families of low socio-economic status, the life of the McEachen family was blighted by economic downturns, famine and social upheaval. The downturn in the kelp industry had a local and national effect. Crofters who had seasonally found employment in kelping could no longer rely on this as a source of cash, as landowners turned from kelp production to giving over land for sheep grazing. The downturn in the economic fortune of the Highlands and Islands was also compounded by the potato famine of the $1840 \mathrm{~s}$. 


\section{CONCLUSIONS}

The excavation and watching brief at Brunary Burn demonstrated that the house and its ancillary structures were of 19th-century origin and were occupied for a short period. Historical records indicate that the house was occupied by the McEachen family some time during the period 1831 to 1851 , who appear in the 1841 census as a family of ten. The family no longer lived at Brunary Burn by the 1851 census, but some family members are listed as residing in a new dwelling, Kinloid Farm. The matriarch of the house was discovered to have died of unknown causes by this time, and at least two of the original family members (daughter Janet and sister Kate) are not listed in the census; one can only speculate about their fate - they may have emigrated, died or married and moved away.
The increase in settlement remains of mid 19th-century date recorded in the Arisaig area, of which the remains at Brunary Burn are an example, probably reflect a growing local population stimulated by economic improvements (kelp production), and landowners keen to populate their estates, particularly in marginal land, in order to create a workforce which could be used on the estate. However, the eventual downturn in the kelp industry meant there was less opportunity for estate tenants to earn the cash necessary to supplement their meagre subsistence on their crofts. The potato blight followed by famine reduced the local population, with further reductions caused by evictions and emigration, resulting in unoccupied houses falling to ruin. 


\section{ACKNOWLEDGEMENTS}

CFA Archaeology Ltd wishes to thank Historic Scotland for their curatorial services in facilitating and funding this project on behalf of the Scottish Ministers. The site archive will be deposited with the National Monuments Record for Scotland and finds will be allocated via the Treasure Trove Panel. Illus- trations are by Ross White and Leeanne Whitelaw. Drafts of the report were commented upon by Sue Anderson, Andrew Dunwell, Tim Neighbour and Rod McCullagh. The final form and opinions expressed in this report remain the responsibility of the authors and CFA Archaeology Ltd. 


\section{ENDNOTES}

1 GD201/5/533, 'Statement of prices of land in Arisaig and others, sold by the Clanranald Trustees to the Trustees of Lady Ashburton, made up in terms of the award of the arbiters in the submission between the parties. 3 August 1833'; and GD210/5 /1226.

2 PP1884, XXXV, Statement by Rev. Donald MacCallum, Church of Scotland Minister at Arisaig.
3 PP1847, LIII, 'Mr. Trevelyan to Sir. E. Coffin, October 6, 1846'.

4 PP1884, XXXV, 'Evidence of Alexander McPherson and Alexander McEachran'.

5 Census, 1851 (Scotland), p 78.

6 PP1895, XXXVIX, Evidence of Allan MacEachan, pp 1219-21.

7 VR103, Valuation Rolls for the County of Inverness, 1901-02. 


\section{REFERENCES}

\subsection{Cartographic references}

Ordnance Survey First Edition (1876) 1:10,560 Scale, Inverness-shire (Mainland) Sheet CXXI

Roy, W (1747-55). Map 12/4d: Area around Loch nam Uamh, in Inverness-shire

\subsection{Records held in the General Register Office, Scotland}

Census enumerator schedules, 1841-1901

Registers of Births, Marriages and Deaths, 1855- .

Old Parish Registers, Index

\subsection{Papers and documents held in the National Archives of Scotland}

GD201 Papers of the MacDonald Family of Clanranald, 1520-1881

VR103 Valuation Rolls for the County of Inverness

\subsection{Parliamentary Papers}

PP1841, VI, 'Report from the Select Committee on Emigration, Scotland'

PP1847, LIII, 'Correspondence relating to the measures adopted for the Relief of Distress in Ireland and Scotland'

PP1884, XXXV, 'Commission of Inquiry into the Condition of the Crofters and Cottars in the Highlands and Islands of Scotland, Evidence, Vol III'

PP1895, XXXVIX, 'Royal Commission, Highlands and Islands (1892), Minutes of Evidence Volume II'

\subsection{Published works}

Alexander, D 1994 Arisaig, Lochaber District, Highland Region. Archaeological Survey. Centre for Field Archaeology, University of Edinburgh. Archive Report No. 161.

Brunskill, R W 1987 Traditional Farm Buildings of Britain. Victor Gollancz, London.

Carter, S, Dalland, M \& Long, D 2005 Early Landuse and Landscape Development in Arisaig. SAIR 15, Edinburgh.

Cruickshank, G 1987 Scottish Pottery. A Brief History. Shire, Aylesbury.

Devine, T M 1988 The Great Highland Famine. John Donald, Edinburgh.

Dixon, P 1994 'Field systems, rig and other cultivation remains in Scotland: the field evidence', in S Foster \& T C Smout (eds) The History of Soils and Field Systems. Scottish Cultural Press, Aberdeen.

Dobson, D 1984 Directory of Scottish Settlers in North America 1625-1825. Genealogical Publishing Co. Inc., Baltimore

Durie, A 2003 Scotland for the Holidays: Tourism in Scotland, c 1780-1939. Tuckwell Press, East Linton.

NSA 1845 'The Parish of Ardnamurchan', The New Statistical Account of Scotland by the Ministers of the respective parishes, Vol VII. William Blackwood, Edinburgh.

Rixson, D 2002 Arisaig and Morar, a History. Tuckwell Press, East Linton.

Stewart, J H \& Stewart, M B 1988 'A Highland longhouse - Lianach, Balquhidder, Perthshire', Proc Soc Antiq Scot, 118 (1988), 301-17.

Suddaby, I 2005 A830 Upgrading, Loch Nan Uamh to Arisaig, Lochaber, Highland. CFA Report No. 1088, unpublished.

Thomas, J 1979 The West Highland Railway. David \& Charles, Newton Abbot.

Whyte, I \& Whyte, K 1987 Exploring Scotland's Historic Landscape. John Donald, Edinburgh. 